\title{
Het opleidingsfonds: verdeling van kwantiteit of kwaliteit?
}

\author{
H.J.L. Brackel
}

\section{Samenvatting}

Sinds 2007 worden de zorgopleidingen bekostigd uit een systeem buiten de zorgbudgetten om: het Opleidingsfonds. Na twee jaar blijken er veel structurele problemen, voor zowel artsen in opleiding tot specialist (aios) en instellingen als op specialisme-niveau, en dit alles met negatieve gevolgen voor de kwaliteit van de opleiding. Dit betoog zet de problemen op een rij om aan te tonen dat het Opleidingsfonds in de huidige vorm de kwaliteit van de opleiding niet ten goede komt. (Brackel HJL. Het Opleidingsfonds: verdeling van kwantiteit of kwaliteit? Tijdschrift voor Medisch Onderwijs 2008;27(6):313-315.)

\section{Inleiding}

Sedert 1 januari 2007 worden de zorgopleidingen bekostigd via een nieuw systeem van 'prestatie'-subsidiëring van opleidingsactiviteiten buiten de zorgbudgetten van de instellingen om. Dit nieuwe systeem is het 'Opleidingsfonds'. In essentie moet dit systeem de oplossing bieden voor de ook in het Ecri-rapport beschreven problemen dat "de markt voor zorgopleidingen faalt" en dat "zorgopleidingen marktverstorend werken bij de introductie van DBC-tarieven in de zorg" ${ }^{1-2}$ Opvallend is dat in de motivatie voor het Opleidingsfonds de kwaliteit van de opleiding ondergeschikt is aan marktargumenten.

In ons land is gekozen voor een op termijn grotendeels door de 'vrije' markt gestuurde zorgfinanciering. Om de continuïteit en kwaliteit van de opleiding van de 'dokters van morgen' te blijven garanderen is het essentieel dat de bekostiging daarvan onafhankelijk is/wordt van de winst- en verliesrekening van de opleidingsinstellingen. De oprichting van het Opleidingsfonds is daarmee in essentie een goede zaak. Na twee jaar ervaring met het Opleidingsfonds zijn echter voor instellingen, opleiders én artsen in oplei- ding tot specialist (aios) veel structurele problemen herkenbaar met aantoonbaar nadeel voor de kwaliteit van de opleiding.

\section{Nadelen op aios-niveau}

- De mogelijkheden een opleidingsschema gedurende het jaar aan te passen aan veranderende omstandigheden (zwangerschap, ziekte, onderzoek, etc.) zijn nu binnen en tussen instellingen vrijwel afwezig. Prestatiesubsidiëring betekent immers: minder opleiden is subsidie terugbetalen. Meer opleiden wordt niet gecompenseerd of beloond en onderling verrekenen mag niet. Detacheren levert hiervoor een te beperkte oplossing. 'Opleiden op maat' wordt hiermee gefrustreerd omdat het de instellingen geld kost. ${ }^{3}$

- Uitval van aios betekent verlies van subsidie en verloren gaan van opleidingsplaatsen, ook voor de daarop volgende jaren. Hiermee wordt een ongewenste incentive geschapen om disfunctionerende aios aan te houden of om een aios, die voortijdig wil stoppen, daartoe te 'ontmoedigen'. 


\section{Nadelen op instellingsniveau}

- De subsidie van de instromende aios is een jaarsubsidie. Dit heeft tot gevolg dat instellingen overgaan tot aanstelling van instromende aios zo dicht mogelijk bij 1 januari om zo verlies aan subsidiegeld dat jaar te voorkomen. Dit leidt tot roosterproblemen en tot ongewenste cumulatie van sollicitatierondes in het laatste kwartaal in meerdere clusters tegelijk, met diverse negatieve gevolgen niet alleen voor solliciterende artsen niet in opleiding tot specialist (anios) maar ook voor afdelingen.

- De opleidingssubsidie is de som van het aios-salaris, de structurele ziekenhuisbrede overheadkosten en het geschatte verlies aan productie bij het opleiden. Het verloren gaan van aiosplekken (stoppen, korting, verhuizen, detachering) betekent ook het verlies van structurele opleidingsinkomsten voor de instelling waarmee noodzakelijke investeringen en onderhoud van voorzieningen (skillslab, e-learning, onderwijsbureau) in het gedrang (kunnen) komen.

- Door het Opleidingsfonds wordt de aios als 'niet essentieel' voor de bedrijfsvoering beschouwd. Binnen de instellingen is de aios een werknemer met salaris van wie inzet bij productie als patiëntenzorg en diensten verwacht wordt. Dit leidt tot een spanningsveld tussen bedrijfsvoering en opleiden, met gevolgen voor de kwaliteit van beide.

- Het Opleidingsfonds betekent een volledige scheiding op macroniveau tussen zorg- en opleidingskosten. Het microniveau (het ziekenhuis) is hier nog niet of onvoldoende op voorbereid, mede omdat de opleidingskosten landelijk maar ook lokaal niet helder zijn. Het bekostigingssysteem is daarmee niet doorgevoerd in de bedrijfsvoering van ziekenhuizen. Dit levert een spanningsveld op tussen opleiders en management in de opleidingsziekenhuizen die hun financiële situatie op orde moeten houden. De beoogde loskoppeling van opleiding van de 'zorgmarkt' dreigt daarmee alsnog te mislukken.

\section{Nadelen op specialisme-niveau}

- De modernisering van de opleiding conform het Kaderbesluit CCMS 2004 (Centraal College Medische Specialismen) eist een grote extra investering en inzet van opleiders en instellingen in tijd, kennis en middelen. Het In VIVO-project is daar een goed voorbeeld van. Het vereist ook meer flexibiliteit van het systeem om aan de nieuwe eisen van het nieuwe opleiden volgens een 'Persoonlijk Ontwikkelplan' (POP) voor iedere aios, te kunnen voldoen. De starre regelgeving van het Opleidingsfonds frustreert deze flexibiliteit met het risico van demotivatie van aios en opleiders om te investeren in de noodzakelijke modernisering van de opleiding.

- Beoogd wordt een 'opleidingsmarkt' met transparantie van kwaliteit en kosten zoals deels in Amerika al langer bestaat. ${ }^{4}$ Het Opleidingsfonds is echter ingevoerd vóórdat de kwaliteit meetbaar en/of de kosten bekend zijn. Onder opleiders en instellingen bestaat weinig vertrouwen in de haalbaarheid van uniforme kwaliteitscriteria. Daarnaast wordt sterk getwijfeld aan de compleetheid van de inventarisatie van opleidingkosten die in opdracht van het ministerie van VWS door organisatieadviesbureau Berenschot wordt uitgevoerd. Hier speelt mee dat deze analyse wordt uitgevoerd vóórdat de herziening van de vervolgopleiding breed is ingevoerd. Men vreest voor bezuiniging op opleidings- 
financiering waarmee de kwaliteitsslag met betrekking tot opleidingsherziening teniet wordt gedaan.

\section{Tenslotte}

Opleiders en instellingen zijn verantwoordelijk voor de opleiding van 'hun' aios en willen dat ook zijn. Bovenstaande tekortkomingen leiden echter tot een breed gevoelde ontevredenheid onder instellingen, opleiders en aios over de verdeling van de opleidingsplaatsen en over de inrichting van hun eigen opleiding. Dat is geen kwestie van nog moeten wennen aan een nieuw systeem, maar een principieel oneens zijn met een nu wel transparant maar verder te simpel systeem dat onvoldoende ruimte biedt voor een 'Opleiding op Maat voor iedere aios'.

Onvoldoende oor voor deze ontevredenheid zal leiden tot verdere frustratie, afnemen van opleidingsinitiatieven en een afkalvende kwaliteit van de opleiding. ${ }^{5}$ De rekening hiervan betalen we later.

Het is een illusie te denken dat er een voor alle partijen bevredigende uniforme 'tover'-oplossing mogelijk is. ${ }^{5-6}$ De verscheidenheid aan belangen en spanningen binnen het opleidingsveld laat dat niet toe. De grondgedachte van het Opleidingsfonds (loskoppeling van bekostiging van opleiding van zorgfinanciering) is goed. Het aspect 'kwaliteit van opleiding' dient echter veel zwaarder de regelgeving te bepalen. Het is de uitdaging gezamenlijk een meer flexibel systeem te maken waarmee de vroeger aanwezige 'regel-/ speel-ruimte' terugkomt en waarmee ook tegemoet gekomen wordt aan de essentiële verschillen tussen aios, specialismen, instellingen en ook OOR's.

\section{Literatuur}

1. Varkevisser $\mathrm{M}$ et al. Naar een meer transparante opleidingsmarkt. Marktprikkels in het opleidingsfonds. Rapport ECRI i.o.v. Ministerie van VWS; december 2006.

2. Hoogervorst H (minister VWS). Brief bij aanbieden Ecri-rapport en kabinetsstandpunt aangaande kwaliteits- en doelmatigheidsprikkels en opleidingsfonds,kenmerk MEVA/NBO-2745530.

3. Pronk E. Verdeling opnieuw op de schop. Systematisch opleidingsfonds medisch specialisten leidt tot veel beroering. Med Contact 2008; 63(15):621-23.

4. Financing Graduate Medical Education to Meet the Needs of Children and the Future Pediatrician Workforce. Committee on Pediatric Workforce Pediatrics 2008; 121: 855-861. (http://www.pediatrics.org/cgi/content/full/121/4/855)

5. Frissen PHA et al. Schaarste tussen politiek en ramingen. Verdeling van opleidingsplaatsen voor medisch specialisten. Concept-Rapport NSOB i.o.v. CBOG; Den Haag: 2008.

6. NieuwsReflex. Geen toverformule voor verdeling opleidingsplaatsen. In: Med Contact nr 11, 14 maart 2008.

\section{De auteur:}

Dr. H.J.L. Brackel, kinderarts en opleider in het Catharina Ziekenhuis te Eindhoven, lid van het In VIVOkernteam Zuidoost-Nederland.

Correspondentieadres:

Dr. H.J.L. Brackel, Catharina Ziekenhuis, Michelangelolaan 2, 5623 EJ Eindhoven.Tel.: 040-2397250; e-mail: hein.brackel@cze.nl

Belangenconflict: geen gemeld

Financiële ondersteuning: geen gemeld

\section{Summary}

Since 2007 the 'Education Fund' has provided funding for postgraduate specialist training which was separate from the hospital service budgets. However, after two years trainees, institutions and specialties are facing many structural problems which impact negatively on the quality of postgraduate training. This article outlines the problems in order to demonstrate that in its current form the 'Education Fund' offers no benefits to the quality of education and training. (Brackel HJL. The 'Education Fund': distribution of quantity or quality? Dutch Journal of Medical Education 2008;27(6):313-315.) 